\title{
EEC syndrome
}

INSERM

\section{Source}

INSERM. (1999). Orphanet: an online rare disease and orphan drug data base. EEC syndrome. ORPHA:1896

EEC syndrome is a genetic developmental disorder characterized by ectrodactyly, ectodermal dysplasia, and orofacial clefts (cleft lip/palate). 